V. D. Rybachuk

National University of Pharmacy

\title{
The choice of fillers when creating natural zeolite tablets by the wet granulation method
}

Tablets are one of the most popular among all pharmaceutical dosage forms. Properties of tablets depend on a number of factors; the content of excipients is the most important of them. Among the complex of excipients of different functional orientation fillers, which can significantly affect the technological properties of tablets, in particular, hardness and friability of tablets, occupy a special place.

Aim. To to select the optimal qualitative composition of fillers for obtaining natural zeolite tablets by the method of wet granulation.

Materials and methods. The objects of research were natural zeolite tablets (10 $\mathrm{mm}$ in diameter) obtained by pressing with the preliminary wet granulation. Model samples contained various fillers, which were the combination of lactose with microcrystalline cellulose (MCC), sorbitol and powdered sugar. A balanced single-factor experiment with equal duplication of experiments was used to select the optimal composition of excipients. Four quantitative factors were studied. The quality of the tablets was assessed by the indicators of uniformity of mass, hardness, friability and disintegration time. In the experiments the modern equipment was used. To conduct the tests the methods of the State Pharmacopoeia of Ukraine (SPhU) were used.

Results and discussion. As a result of the analysis of the data obtained it has been found that both the type and concentration of fillers affect the pharmaco-technological properties of tablets. The studies conducted showed that among the types of fillers studied, including mixtures of lactose with MCC, sorbitol and powdered sugar in different proportions, the best results according to four technological factors, namely uniformity of mass, hardness, friability and disintegration time of tablets, were demonstrated by the combination of lactose with MCC in the ratio of $1: 1$. It was this combination that we chose for further research to create natural zeolite.

Conclusions. The studies on selection of the qualitative composition of fillers for creation of natural zeolite tablets by pressing with the preliminary wet granulation have been performed, and the optimal composition of fillers has been proposed to provide the production of tablets which properties correspond to the current requirements of the SPhU.

Key words: natural zeolite; clinoptilolite; tablets; excipients; fillers; wet granulation

\section{В. Д. Рибачук}

\section{Підбір наповнювачів для створення таблеток цеоліту природного методом вологої грануляції}

Таблетки - найпопулярніша серед усіх фрармацевтичних препаратів лікарська форма. Властивості таблеток залежать від низки чинників, найважливішими з яких $є$ вміст допоміжних речовин. Серед комплексу допоміжних речовин різної фрунціональної спрямованості особливе місце посідають наповнювачі, здатні істотно впливати на технологічні властивості, зокрема, механічну міцність та стираність таблеток.

Мета роботи. Обрати якісний склад наповнювачів для отримання таблеток цеоліту природного методом вологої грануляції.

Матеріали та методи. Об'єктами досліджень слугували таблетки цеоліту природного (діаметром 10 мм), отримані пресуванням з попередньою вологою грануляцією. Модельні зразки містили різні наповнювачі, що являють собою комбінацію лактози з мікрокристалічною целюлозою, сорбітом та цукровою пудрою. Для вибору оптимального складу наповнювачів використовували збалансований однофакторний експеримент з рівним дублюванням дослідів. Було вивчено 4 кількісні фрактори. Якість таблеток оцінювали за показниками однорідності маси, механічної міцності, стираності та часу розпадання. У дослідах використовували сучасне обладнання. Для тестів користувалися методиками Державної фрармакопеї України.

Результати та їх обговорення. У результаті аналізу отриманих даних встановлено, що на фармакотехнологічні властивості таблеток впливають як вид, так і концентрація наповнювачів. Проведені дослідження показали, що з вивчених видів наповнювачів, що включали суміші лактози з МКЦ, сорбітом та цукровою пудрою у різному співвідношенні, найкращі результати за чотирма вивченими технологічними факторами, а саме однорідністю маси таблеток, механічною міцністю, показником стираності та часом розпадання найкращі результати продемонструвала комбінація лактози з мікрокристалічною целюлозою у співвідношенні 1 : 1. Саме ця комбінація була нами обрана для подальших досліджень зі створення таблеток цеоліту природного.

Висновки. Проведено дослідження з підбору якісного складу наповнювачів для отримання таблеток цеоліту природного пресуванням з попередньою вологою грануляцією та запропоновано оптимальний склад наповнювачів, що забезпечують отримання таблеток, властивості яких відповідають діючим вимогам ДФУ.

Ключові слова: цеоліт природний; кліноптилоліт; таблетки; допоміжні речовини; наповнювачі; волога грануляція 


\section{В. Д. Рыбачук}

\section{Выбор наполнителей для создания таблеток цеолита природного методом влажной грануляции}

Таблетки являются одной из самых популярных среди всех фрармацевтических лекарственных форм. Свойства таблеток зависят от ряда факторов, важнейшим из которых является содержание вспомогательных веществ. Среди комплекса вспомогательных веществ различной функциональной направленности особое место занимают наполнители, которые способны существенно влиять на технологические свойства таблеток, в частности, механическую прочность и истираемость таблеток.

Цель работы. Выбрать оптимальный качественный состав наполнителей для получения таблеток цеолита природного методом влажной грануляции.

Материалы и методы. Объектами исследований служили таблетки цеолита природного (диаметром 10 мм), полученные прессованием с предварительной влажной грануляцией. Модельные образцы содержали различные наполнители, представляющие собой комбинацию лактозы с микрокристаллической целлюлозой, сорбитом и сахарной пудрой. Для выбора оптимального состава наполнителей использовали сбалансированный однофракторный эксперимент с равным дублированием опытов. Было изучено 4 количественных фактора. Качество таблеток оценивали по показателям однородности массы, механической прочности, истираемости и времени распадаемости. В опытах использовали современное оборудование. Для проведения тестов пользовались методиками Государственной фрармакопеи Украины.

Результаты и их обсуждение. В результате анализа полученных данных установлено, что на фрармакотехнологические свойства таблеток влияют как вид, так и концентрация наполнителей. Проведенные исследования показали, что среди изученных видов наполнителей, включающих смеси лактозы с МКЦ, сорбитом и сахарной пудрой в разном соотношении, лучшие результаты по четырем изученным технологическим факторам, а именно однородности массы таблеток, механической прочности, истираемости и времени распадаемости лучшие результаты продемонстрировала комбинация лактозы с микрокристаллической целлюлозой в соотношении $1: 1$. Именно эта комбинация была нами выбрана для дальнейших исследований по созданию таблеток цеолита природного.

Выводы. Проведены исследования по подбору качественного состава наполнителей для получения таблеток цеолита природного прессованием с предварительной влажной грануляцией и предложен оптимальный состав наполнителей, обеспечивающих получение таблеток, свойства которых соответствуют действующим требованиям ГФУ.

Ключевые слова: цеолит природный; клиноптилолит; таблетки; вспомогательные вещества; наполнители; влажная грануляция

Tablets are one of the most popular among all pharmaceutical dosage forms. The main advantage of this form is convenience for a patient, accuracy of dosing, the ease of mass production and high cost effectiveness. An integral part of most prescriptions of tablet formulations is the presence of excipients that directly affect the quality of the finished dosage form [1].

Excipients are used in tablets to facilitate the process of manufacturing or to enhance the properties of the active ingredient, and their rational choice is necessary when obtaining tablets with adequate properties. Among the complex of excipients of different functional orientation a special place is occupied by fillers that are present in almost all compositions of tablets. Fillers can serve a variety of technological purposes, and not just to provide the required weight of tablets. Along with moisturizers they can also significantly affect the hardness and friability of tablets. Therefore, their careful selection is necessary when developing the dosage form composition $[2,3]$.

Polymers (dextrin, gelatin, polyvinylpyrrolidone, etc.), sugars and polyols (dextrose, lactose, mannitol, sorbitol, sucrose, etc.), amino acids ( $\beta$-alanine, glycine, histidine), salts and buffers (potassium and sodium acetate, calcium chloride, citric acid, sodium citrate, sodium bicarbonate, phosphates and potassium hydrophosphates, zinc chloride, etc.) are most widely used as fillers $[4,5]$.
In our previous studies on selection of the optimal excipients for production of zeolite tablets by wet granulation it was found that the best results for the pharmacotechnological parameters of zeolite tablets were obtained when using $7 \%$ potato starch paste (a binding component), potato starch (a desintegrant) and calcium stearate (a lubricant). Fillers were also studied, and their effect on the properties of natural zeolite tablets proved to be very significant. Therefore, it requires a further detailed study on the choice of representatives of this group of substances in the formulation of tablets $[6,7]$.

The aim of the work was to select the qualitative composition of fillers for obtaining natural zeolite tablets by the method of wet granulation.

\section{Materials and methods}

The objects of research were natural zeolite tablets obtained by pressing with pre-wet granulation. Tablets were pressed on a laboratory tablet machine (Ukraine, Mariupol Plant of Technological Equipment) using a $10 \mathrm{~mm}$ diameter matrix. When preparing the formulation of tablets the following ratios (per 1 tablet) were were used: natural zeolite (clinoptilolite) $-0.400 \mathrm{~g}$, filler $-0.08 \mathrm{~g}$, potato starch $-0.025 \mathrm{~g}$, a binder solution $(7 \%$ potato starch paste) - as much as suffices to obtain a plastic mass. The mass was forced through a sieve with the particle size of $2 \mathrm{~mm}$ and dried in a drying chamber at a tempera- 
ture of $50^{\circ} \mathrm{C}$. The dry mass was sieved through a sieve with the particle size of $1 \mathrm{~mm}$, lubricated with calcium stearate in the amount of $1 \%$ and compressed. When optimizing the composition of tablets four quantitative factors were studied, such as uniformity of mass, hardness, friability and disintegration time of tablets. In the experiments the modern equipment for determining uniformity of mass of tablets (RADWAG PS510/C/2, Poland), friability (Pharma Test D-63512 Hainburg, Germany), disintegration time (Pharma Test PTWS 120S, Germany) and hardness (Pharma Test RTV 111 EP Hainburg, Germany) was used. To conduct the tests the methods of the State Pharmacopoeia of Ukraine (SPhU) were used [8].

To select the optimal filler a balanced single-factor experiment with equal duplication of experiments was used. The planning of the experiment was carried out according to the algorithm given in the monograph "Mathematical planning of the experiment when conducting research in pharmacy" [9]. The adequacy of the models and the statistical significance of the coefficients were verified using the F-criterion. According to the results of the experimental studies the dispersion analysis of the experimental data was performed, and conclusions were made about the effect of the type of the filler on the quality indices of these tablets.

\section{Results and discussion}

Taking into account the properties of natural zeolite [10] and the peculiarities of its further application as an enterosorbent 9 types of fillers and their combinations were chosen for our studies: a1 - the mixture of lactose with microcrystalline cellulose (MCC) in the ratio of
$1.0: 0.5, \mathrm{a} 2$ - the mixture of lactose with MCC in the ratio of $1.0: 1.0, \mathrm{a} 3$ - the mixture of lactose with MCC in the ratio of $0.5: 1.0, \mathrm{a} 4$ - the mixture of lactose with sorbitol in the ratio of $1.0: 0.5$, a5 - the mixture of lactose with sorbitol in the ratio of $1.0: 1.0, \mathrm{a} 6$ - the mixture of lactose with sorbitol $0.5: 1.0$, a7 - the mixture of lactose with powdered sugar in the ratio of $1.0: 0.5$, a 8 - the mixture of lactose with powdered sugar in the ratio of $1.0: 1.0$, a9 - the mixture of lactose with powdered sugar in the ratio of $0.5: 1.0$. The experimental design matrix for a balanced single-factor plan of the experiment and the results of the studies are presented in Table.

As a result of the dispersion analysis of the experimental data (see Table) the conclusion was made about the effect of all fillers studied on the pharmaco-technological properties of the powdered mass and natural zeolite tablets (clinoptilolite). Fig. 1 shows the effect of fillers on the uniformity of mass of tablets. Attention should be drawn to the fact that the uniformity of mass of tablets for all fillers used corresponds to pharmacopoeial standards. The best indicators were observed when adding the mixture of lactose and MCC in the ratio of $1: 1$, while the worst indicators were when adding the mixture of lactose and sorbitol. In general, the effect of fillers on the uniformity of mass can be represented in the following series $\mathrm{a} 2=\mathrm{a} 1=\mathrm{a} 3>\mathrm{a} 7=\mathrm{a} 8>\mathrm{a} 9>\mathrm{a} 4>\mathrm{a} 5=\mathrm{a} 6$.

The results of the dispersion analysis have shown that the hardness of tablets is influenced by all the excipients studied, and the value of their effects is different (Fig. 2). The results obtained indicate that the best re-

Table

A balanced single-factor plan of the experiment and the results of the studies of natural zeolite tablets (clinoptilolite)

\begin{tabular}{|l|c|c|c|c|c|c|c|c|c|c|c|c|}
\hline \multicolumn{1}{|c|}{ Batch code } & $\mathrm{y}_{1}$ & $\mathrm{y}_{1}{ }^{\prime}$ & $\mathrm{y}_{1}{ }^{\prime \prime}$ & $\mathrm{y}_{2}$ & $\mathrm{y}_{2}{ }^{\prime}$ & $\mathrm{y}_{2}{ }^{\prime \prime}$ & $\mathrm{y}_{3}$ & $\mathrm{y}_{3}{ }^{\prime}$ & $\mathrm{y}_{3}{ }^{\prime \prime}$ & $\mathrm{y}_{4}$ & $\mathrm{y}_{4}{ }^{\prime}$ & $\mathrm{y}_{4}{ }^{\prime \prime}$ \\
\hline $\begin{array}{l}\text { a1 - the mixture of lactose with MCC } \\
\text { in the ratio of } 1.0: 0.5\end{array}$ & 0.85 & 0.86 & 0.88 & 104 & 103 & 102 & 0.26 & 0.27 & 0.29 & 1.18 & 1.2 & 1.15 \\
\hline $\begin{array}{l}\text { a2 - the mixture of lactose with MCC } \\
\text { in the ratio of } 1.0: 1.0\end{array}$ & 0,78 & 0,77 & 0,75 & 106 & 108 & 108 & 0,25 & 0,27 & 0,24 & 1,15 & 1,13 & 1,16 \\
\hline $\begin{array}{l}\text { a3 - the mixture of lactose with MCC } \\
\text { in the ratio of 0.5 } 1.0\end{array}$ & 0.87 & 0.88 & 0.86 & 95 & 94 & 95 & 0.35 & 0.34 & 0.34 & 1.15 & 1.1 & 0.95 \\
\hline $\begin{array}{l}\text { a4 - the mixture of lactose with } \\
\text { sorbitol in the ratio of 1.0 } 0.5\end{array}$ & 2.25 & 2.25 & 2.25 & 89 & 90 & 91 & 0.43 & 0.42 & 0.43 & 2.53 & 2.55 & 2.52 \\
\hline $\begin{array}{l}\text { a }- \text { the mixture of lactose with } \\
\text { sorbitol (1.0:1.0) }\end{array}$ & 2.65 & 2.7 & 2.68 & 85 & 88 & 86 & 0.45 & 0.48 & 0.49 & 2.79 & 2.8 & 2.78 \\
\hline $\begin{array}{l}\text { a6 - the mixture of lactose with } \\
\text { sorbitol (0.5:1.0) }\end{array}$ & 2.76 & 2.8 & 2.79 & 81 & 80 & 79 & 0.65 & 0.62 & 0.63 & 3.1 & 3.2 & 3.1 \\
\hline $\begin{array}{l}\text { a7 - the mixture of lactose with } \\
\text { powdered sugar (1.0:0.5) }\end{array}$ & 1.65 & 1.6 & 1.62 & 67 & 69 & 70 & 0.65 & 0.66 & 0.67 & 1.12 & 1.13 & 1.15 \\
\hline $\begin{array}{l}\text { a8 - the mixture of lactose with } \\
\text { powdered sugar (1.0:1.0) }\end{array}$ & 1.78 & 1.75 & 1.72 & 65 & 66 & 65 & 0.75 & 0.76 & 0.75 & 1.25 & 1.18 & 1.2 \\
\hline $\begin{array}{l}\text { a9 - the mixture of lactose with } \\
\text { powdered sugar (0.5:1.0) }\end{array}$ & 1.95 & 1.92 & 1.97 & 59 & 62 & 61 & 0.88 & 0.91 & 0.9 & 0.95 & 0.92 & 0.93 \\
\hline
\end{tabular}

Notes: $y_{1}, y_{1}^{\prime}, y_{1}{ }^{\prime \prime}$ - the uniformity of mass of tablets from the first, the second and the third series of the experiment, respectively, \%; $\mathrm{y}_{2}, \mathrm{y}_{2}^{\prime}, \mathrm{y}_{2}^{\prime \prime}-$ the hardness of tablets of the first, second and third series of the experiment, respectively, $N ; \mathrm{y}_{3}, \mathrm{y}_{3}{ }^{\prime}, \mathrm{y}_{3}{ }^{\prime \prime}-$ the friability of tablets of the first, second and third series of the experiment, respectively, $\% ; y_{4}, y_{4}^{\prime} y_{4}^{\prime \prime}$ - the disintegration time of tablets of the first, second and third series of experiment, respectively, min. 


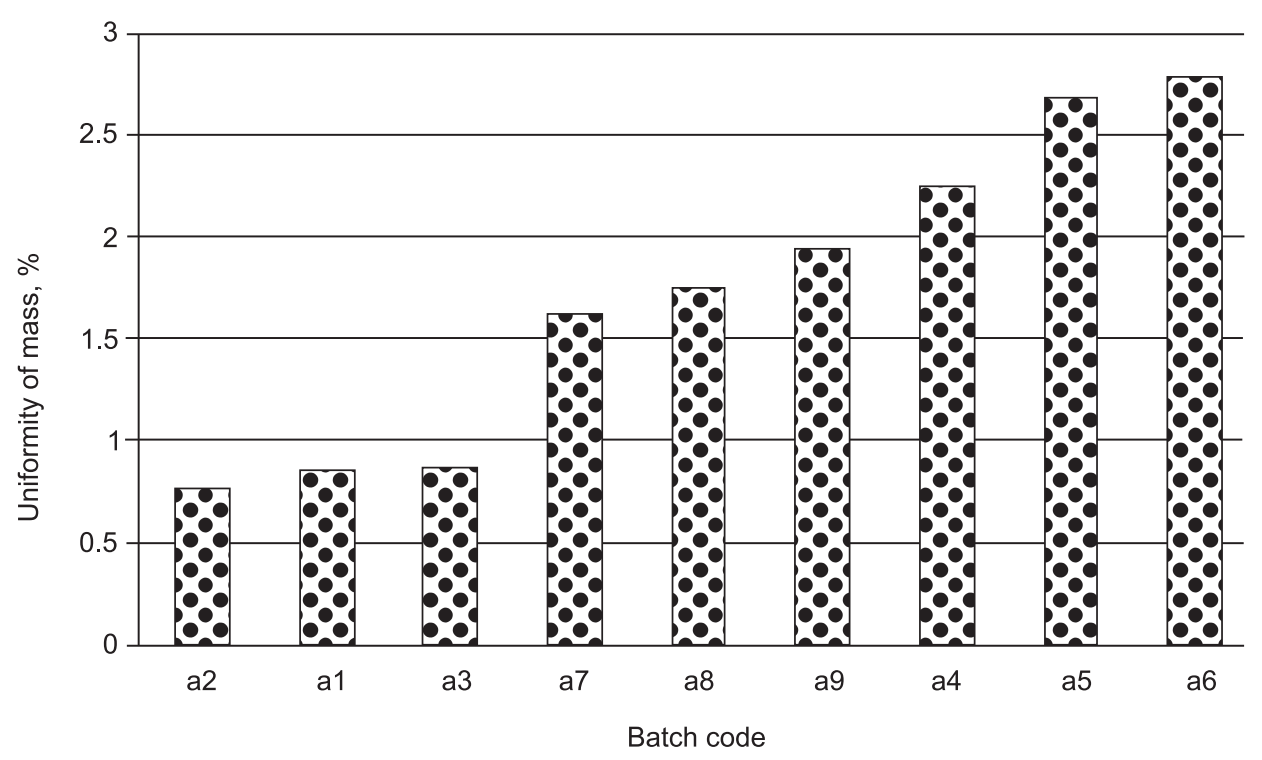

Fig. 1. The effect of fillers on the uniformity of mass of tablets

sults are provided by the combination of lactose with MCC, but addition of sorbitol and powdered sugar, on the contrary, is negatively impacted on the hardness of the resulting samples of tablets. It was determined that when using the combination of lactose with MCC the average value of the friability of tablets was maximal and was 94.6-107.3 $\mathrm{N}$ depending on their ratio, and when using lactose in the combination with sorbitol and powdered sugar it decreased significantly and was $83.6-90 \mathrm{~N}$ and 70.6-78.6 N, respectively. The best indicators were also observed when adding the mixture of lactose with MCC in the ratio of $1.0: 1.0(107.3 \mathrm{~N})$. In general, the effect of fillers can be represented as a2 $>$ a1 $>$ a $3>$ a $4>$ $\mathrm{a} 5=\mathrm{a} 6>\mathrm{a} 7=\mathrm{a} 8>\mathrm{a} 6$.

The results of the dispersion analysis have shown that the data obtained completely correlate with the values of hardness, the effect of all types of fillers studied on the friability of natural zeolite tablets (Fig. 3), and the results fully comply with the requirements of the $\mathrm{SPhU}$ [8]. By the effect on the friability of tablets fillers can be placed in the following order: $\mathrm{a} 2=\mathrm{a} 1>\mathrm{a} 3>\mathrm{a} 4=\mathrm{a} 5>$ $\mathrm{a} 6=\mathrm{a} 7>\mathrm{a} 8>\mathrm{a} 9$.

The results of the dispersion analysis have shown that only addition of sorbitol affects the disintegration time in the direction of its increasing. Fig. 4 demonstrates the values of the disintegration time of tablets depending on the filler type. Among the excipients studied the best results were obtained from granules containing lactose in the combination with MCC and powdered sugar (0.9-1.21 min). By the effect on the disintegration time of tablets fillers can be arranged in the following sequence: $\mathrm{a} 9=\mathrm{a} 3=\mathrm{a} 7=\mathrm{a} 2=\mathrm{a} 1=\mathrm{a} 8>\mathrm{a} 4>\mathrm{a} 5>\mathrm{a} 6$.

The studies conducted showed that among the types of fillers studied, including mixtures of lactose with MCC, sorbitol and powdered sugar in different proportions, the best results according to four technological factors, namely

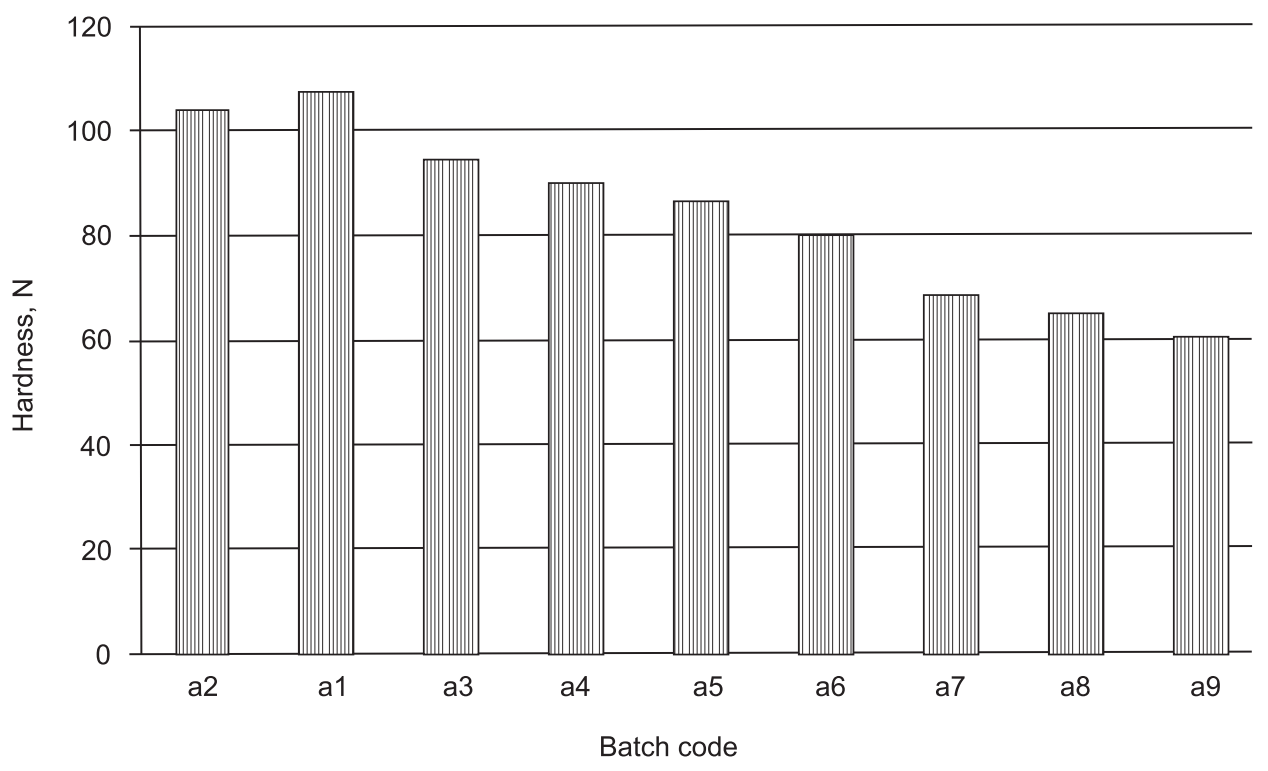

Fig. 2. The effect of fillers on the hardness of tablets 


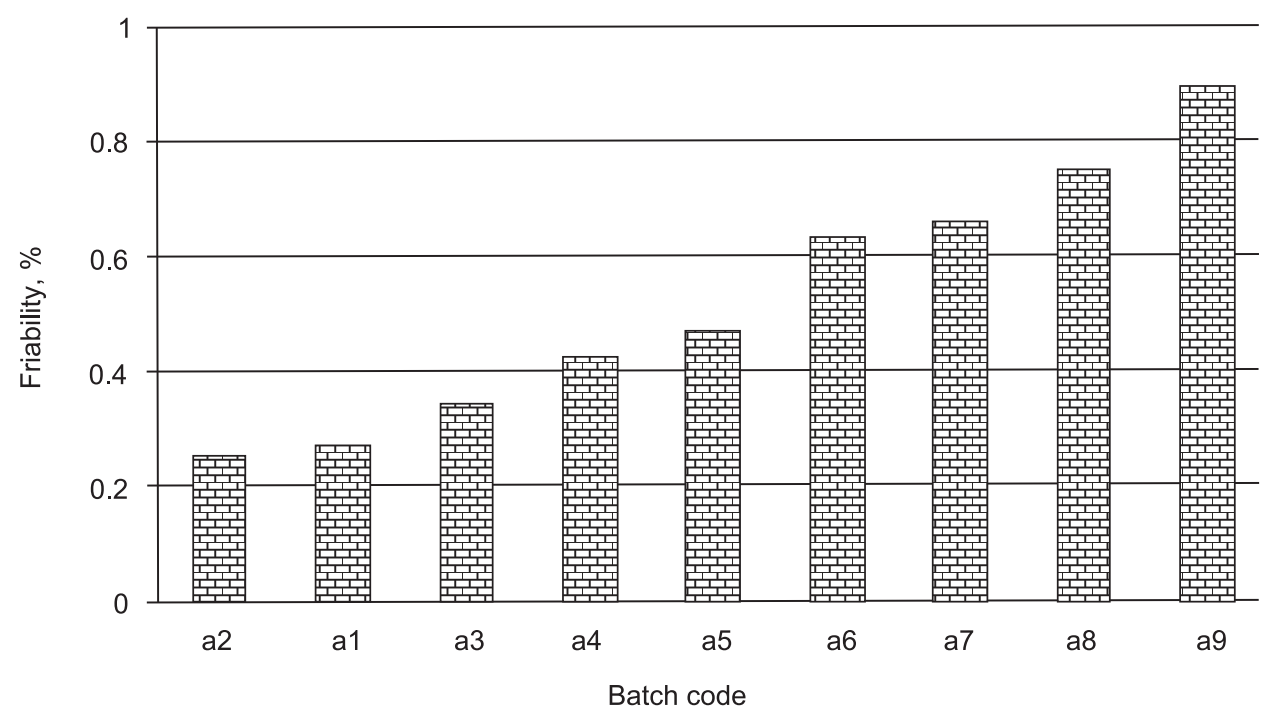

Fig. 3. The effect of fillers on the friability of tablets

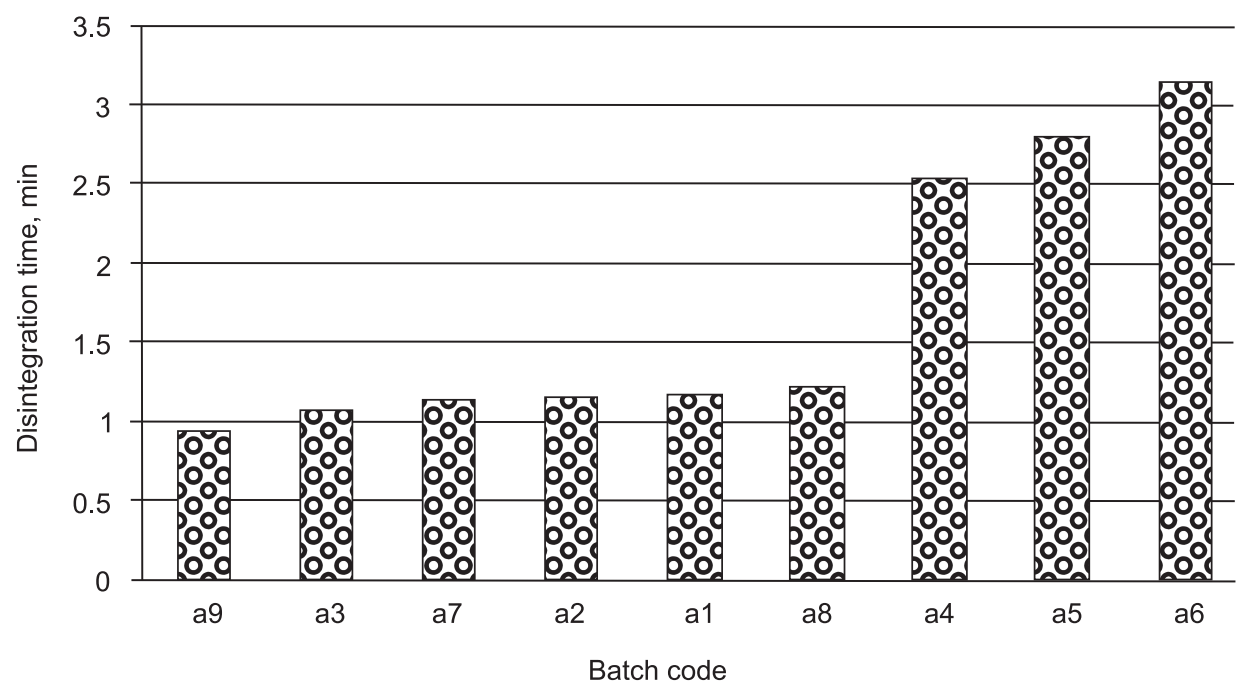

Fig. 4. The effect of fillers on the Disintegration time of tablets

uniformity of mass, hardness, friability and disintegration time of tablets, were demonstrated by the combination of lactose with MCC in the ratio of $1: 1$. It was this combination that we chose for further research to create natural zeolite tablets.

\section{CONCLUSIONS}

1. The effect of fillers on the technological characteristics of natural zeolite tablets has been studied; and the possibility of their production using the wet granulation method has been confirmed.

2. The filler selected, namely, the mixture of lactose with microcrystalline cellulose in the ratio of $1: 1$ has shown better results; it will be used to obtain natural zeolite tablets (clinoptilolite).

Conflicts of Interest: authors have no conflict of interests to declare.

\section{REFERENCES}

1. Eyjolfsson, R. Design and Manufacture of Pharmaceutical Tablets / R. Eyjolfsson. - NY: Academic Press, 2014. - 55 p. https://doi.org/10.1016/ c2014-0-02382-9

2. Excipient selection can significantly affect solid-state phase transformation in formulation during wet granulation / S. I. Airaksinen, M. Karjalainen, N. Kivikero et al. // AAPS PharmSciTech. - 2005. - № 6 (2). - P. 311-322. https://doi.org/10.1208/pt060241

3. Drug-excipient(s) interactions and compatibility study: A Review / M. Zaki Ahmad, A. Kumar, V. Kumar, S. Akhter // J. of Pharm. Res. - 2010. - № 3 (9). - P. 2092-2095.

4. Chaudhari, S. P. Pharmaceutical Excipients: A review / S. P. Chaudhari, P. S. Patil // IJAPBC. - 2012. - № 1 (1). - P. $21-34$.

5. Рибачук, В. Д. Наповнювачі / В. Д. Рибачук // Фармацевтична енциклопедія. - Вид. 3-е, доп. - К. : Моріон, 2016. - С. 1137.

6. Рибачук, В. Д. Вивчення впливу допоміжних речовин на пресуємість порошку цеоліту природного / В. Д. Рибачук, Д. В. Рибачук // Вісник фармації. - 2010. - № 3. - С. 11-14.

7. Рыбачук, В. Д. Выбор рациональных вспомогательных веществ для создания таблеток цеолита природного / В. Д. Рыбачук // Рецепт. - 2018. - № 4. - С. 484-491. 
8. Державна фармакопея України : у 3 т. Т. 1 / Державне підприємство «Науково-експертний фармакопейний центр». - X. : Державне підприємство «Науково-експертний фармакопейний центр», 2015. - 1128 с.

9. Математичне планування експерименту при проведенні наукових досліджень в фармації / Т. А. Грошовий, В. П. Марценюк, Л. І. Кучеренко та ін. - Тернопіль : Укрмедкнига, 2008. - 368 с.

10. Рыбачук, В. Д. Экспериментальная оценка свойств цеолита природного с позиции его соответствия требованиям для энтеросорбентов / В. Д. Рыбачук // Рецепт. - 2016. - № 6. - С. 668-674.

\section{REFERENCES}

1. Eyjolfsson, R. (2012). Design and Manufacture of Pharmaceutical Tablets. New York:Academic Press, 55 p. https://doi.org/10.1016/ c2014-0-02382-9

2. Airaksinen, S. I., Karjalainen, M., Kivikero, N., Westermarck, S., Shevchenko, A., Rantanen, J., Yliruusi, J. (2005). Excipient selection can significantly affect solid-state phase transformation in formulation during wet granulation. AAPS PharmSciTech, 6 (2), 311-322. https://doi.org/10.1208/pt060241

3. Zaki Ahmad, M., Kumar, A., Kumar, V., Akhter, S. (2010). Drug-excipient(s) interactions and compatibility study: A Review. Journal of Pharmacy Research, № 3 (9), 2092-2095.

4. Chaudhari, S. P., Patil, P. S. (2012). Pharmaceutical Excipients: A review. IJAPBC, 1 (1), 21-34.

5. Rybachuk, V. D. (2016). Napovniuvachi. Farmatsevtychna entsyklopediia. (3 edition). Kyiv: Morion, 1137.

6. Rybachuk, D. V., Rybachuk, V. D. (2010). Visnik farmaciï, 3, 11-14.

7. Rybachuk, V. D. (2018). «Retsept», 4, 484-491.

8. Derzhavne pidpryiemstvo «Ukrainskyi naukovyi ekspertnyi farmakopeinyi tsentr yakosti likarskykh zasobiv». (2015). Derzhavna farmakopeia Ukrainy. (Vol. 1). Kharkiv, 1128.

9. Hroshovyi, T. A., Martsenyuk, V. P., Kucherenko, L. I., Vronska, L. V., Huryeyeva, C. M. (2008). Matematychne planuvannia eksperymentu pry provedenni naukovykh doslidzhen v farmatsii. Ternopil: Ternopil State Medical University Ukrainian, 368.

10. Rybachuk, V. D. (2016). «Retsept», 6, $668-674$.

\section{Information about authors:}

Rybachuk V. D., Candidate of Pharmacy (Ph. D), associate professor of the Department of Industrial Technology of Drugs, National University of Pharmacy.

E-mail: v.d.rybachuk@gmail.com. ORCID: http://orcid.org/0000-0002-7887-0298

Відомості про авторів:

Рибачук В. Д., канд. фарм. наук, доцент кафедри заводської технології ліків, Національний фармацевтичний університет. Е-таil: v.d.rybachuk@gmail.com.

ORCID: http://orcid.org/0000-0002-7887-0298

Сведения об авторах:

Рыбачук В. Д., канд. фарм. наук, доцент кафедры заводской технологии лекарств, Национальный фармацевтический университет.

E-mail: v.d.rybachuk@gmail.com. ORCID: http://orcid.org/0000-0002-7887-0298 